Baran-Szołtys, M., Glosowitz, M. and Konarzewska, A. (eds.): Imagined Geographies: Central European Spatial Narratives between 1984 and 2014. Stuttgart, ibidem Press, 2018. 170 p.

"No. «To die for one's country and for Europe» - that is a phrase that could not be thought in Moscow or Leningrad; it is precisely the phrase that could be thought in Budapest or Warsaw" (Kundera, M. 1984, 33). This is how Milan Kundera concludes the first paragraph of his famous essay The Tragedy of Central Europe, and this is how one can best grasp the quintessence of this book. Similar to the great Czech writer Kundera, the editors of the book and the authors of the five different chapters are interested in how the 'notion of Central Europe' is envisioned, conceptualised and perceived both geographically and culturally. Or, to put it more simple, they are trying to uncover what exactly lies beneath the term Central Europe - "regions in eastern middle Europe that attempted to 'move to the West"' (p. 9). Is it truly an imagined space only or is it something more than a permanent desire to belong to the West?

To answer these questions about the phenomenon called Central Europe the book includes one plus four essays, each uncovering a different aspect of the problem. The first essay "Introduction. Central Europe and Its 30 Good Years (1984-2014)" by Aleksandra

Literature and Culture in Central and Eastern Europe

Magdalena Baran-Szołtys, Monika Glosowitz, Aleksandra Konarzewska (eds.)

\section{Imagined Geographies}

Central European Spatial

Narratives between

1984 and 2014

Volume 17

ibidem
KonARzewsKa gives the reader an overview about the past and the present of Central Europe, and introduces the different historical processes which led to the modern conceptualisation of spatial narratives. It might not be clear to someone who is not entirely familiar with the past of Central European countries why the imagined space and the various cultural narratives play such an important role in the life of people living there. To understand it I would like to rely on Jerzy Pilch's following sentence - cited by KonARzewsKA - from his short text The Decalogue of a True European: "[m]y grandma never travelled abroad; it was the frontiers of various countries and European powers that used to fly over the roof of our cottage as only they wanted to" (p. 21).

In the second study, Iris Llop gives a detailed analysis about Milan KunderA's idea of Central Europe, which reconnects with the departure point of the book. The study focuses on how Kundera developed and improved his theory about Central European identity - which was first "the historical and political point of view of a writer in exile" (p. 46), becoming later a narrative strategy representing the diverse forms of Central European identity. As LLOP remarks, KunderA was preoccupied in the early 1980s with the Western misunderstanding of the situation of Central Europe. The West imagined and treated the region as a political creation, the westernmost conquests of the Soviet Union and the geographical and cultural narratives were pushed aside. In KunderA's notion, however, Central Europe was a cultural tradition or a fate which is indifferent from political borders. This led him - as a final conclusion - to treat and write about Central European identity as a narrative construction, something which is constantly changing and can be deconstructed and then reassembled from the different points of view of literary characters. KunderA's Central European identity - through his 'novelistic thinking' - is a "cultural background, a common historical fate and a collective memory, but above all approximations, ... an idea that needs to be rewritten, redefined by the artist that have been determined by its influence and by those ... who are committed to the Central European heritage" (p. 46).

In the two following studies, Jagoda WierzejsKa and Magdalena BARAN-SzoŁtys discuss Galicia and its representations in literature as the region is a prime example of Central Europe as an imagined space, as the buffer between East and West. In the chapter "Galicia: An Eastern or Western Land?" WiERzEJSKA forms her discussion around how spatial narratives revolving around Galicia transformed, according to the political goals of either the empire that ruled over the region or the ethnical group(s) which wanted to 
distance themselves from this empire throughout history. Galicia has always been conceptualised as a symbol of East-West dichotomy since it became a focal point for the modernisation of the Habsburg Empire. However, while the territory was described as barbaric, backward or simply just half-Asia (which is the subtitle of a six-book-volume written by Karl Emil Franzos about Galicia, Bukovina, Southern Russia and Romania) during the Josephinian reforms, in the nineteenth century, still as a part of the Habsburg Empire, it transformed into the 'last bastion' of Western culture. With the expansion of the Russian Empire from the East, the Occident constructed a new Orient for itself. A mostly political tension, the fear from a potential Russian invasion, rewrote the spatial narrative of Austria and shifted the imagined geographies. Later, the discourse around Galicia and its Western roots gained importance for the Galician Poles who believe(d) that the foundation of their prospective autonomy lies in the Habsburg history of Galicia. In recent times, pro-EU thinkers in Western Ukraine are the ones who are shaping the spatial narrative of Galicia against a pro-Russian Eastern Ukraine. As Wierzejska notes, during the Cold War period and after the transitions between 1989 and 1991 the discussion around Galicia remained on the national level in Poland and Ukraine, though the (re)construction of spatial narratives and the forces responsible for it mainly remained the same.

Magdalena BARAN-SzOŁtYs' chapter discusses how one can distance themselves from the 'great tales' and, instead of using spatial narratives to fill a geographical space with meaning, how one can create their 'own middle Europe.' In her study she presents the contemporary Polish writer Andrzej Stasiuk's conceptualisation of the imagined Central Europe. As BARAN-SzoŁty puts it, he "develops the idea of Central Europe in such a way that it could avoid the catastrophic ... dichotomy of East versus West" (p. 70). For Stasiuk, Galicia is a ground zero during the construction of Central Europe. The region (alongside with Kresy and Sarmatia) appears in his literature as a myth, a nostalgic, half-fictional Atlantis-like space (see p. 90), which is a hybrid, transcultural territory, a buffer or better said a transition between the cultures around and inside it. Although StAsiuk is seen as a mediator between East and West, both as a publisher and writer, in his works he tries to distance himself from this (mostly) geopolitical dichotomy of the liberal, capitalist West and the post-Soviet, authoritarian East. Eventually, his Galicia (and also his Central Europe) becomes an in-between non-space rather than a space imagined by a geopolitical power. Comparing STASIUK's viewpoint to the views about Galicia which are constructed according to political goals and needs, one can acknowledge that the main difference lies in the initial intentions. While most imagined geographies and spatial narratives are constructed according to a certain demand, STASIUK rather constructs a nonspace to fill it with the products of his imagination or, as he puts it, Middle Europe is "a microcosm, which enables an imaginative, historical-philosophical reconstruction of 'Other Europe'"' (p. 87).

The final chapter of the book compares nostalgia - a longing for an idealised past fuelled by the deficiencies of the present-to the notion of Central Europe as an imagined space. The author, Mariella C. Gronenthal, once again returns to Andrzej Stasiuk and his ideas about Central Europe which get materialised as a "blank screen for projections" (p. 131). If Central Europe is imagined as an empty canvas, it can be filled then with various cultural, political or historical interpretations coming from diverse directions. Therefore, STAsiuk's 'own middle Europe' "shows ... structural parallels to reconstructing the past in nostalgic memories" (p. 132). The past is vague and unclear, and nostalgic memory can fill it up with fictional characteristics originating from the longings of the present. Similarly, Central Europe is wild, untamed and indefinite, thus it can be filled with different spatial narratives. Both the notion of Central Europe - with its strong historical roots, regionalism and local identities - and nostalgia are intertwining space and time. Central Europe is an ever-changing, situation-based entity, which has always been based on the action of distancing itself from another entity (e.g. the East, the West). Nostalgia is a state where someone distances themselves from the present and turns to an idealised past. Finally, both can be considered as a Thirdspace (SoJA, E. 1996), an in-between space modelled by the past (in the case of nostalgia) or an actual geographical space (in the case of Central Europe) but also fuelled with the fictional idealisation of a phenomenon or a private/collective goal.

In the previous pages I described the content of Imagined Geographies and praised the book and its authors. However, I must note that the volume has a few minor deficiencies in my view. As I mentioned, the first chapter gives a great historical overview about Central Europe but, being more embedded in history and less in literary tradition, it unfortunately leads to a trivial break in the otherwise very coherent composition of the volume. It could have been a better solution to integrate the ideas presented in this chapter within the other sections. Another shortcoming is the title of the book, which can be considered as deceptive. Edward SAID's (1978) and Benedict ANDERson's (1983) work immediately came into my mind when I first held the volume in my hand. The intertextual connection with these authors suggests that the reader will be involved in a journey influenced heavily by the geographical thought, while the book's odyssey actually takes us more into the world of literature and its spatial narratives. This unbalance between the two disciplines is conspicuous if we contrast the title with the text. Finally, it is always tiresome and challeng- 
ing to engage and submerge in such a controversial discourse as the one about 'in-between Europe.' Obviously, the authors make arguments which might seem odd or incorrect from different points of view but it is always important to keep in mind the origins of the thoughts presented and the situation-based knowledge of the scholars who created them.

Nonetheless, what is remarkable about Imagined Geographies: Central European Spatial Narratives between 1984 and 2014 is the way its authors combine the theories of acknowledged scholars and thinkers such as Edward SAID (1978), Benedict Anderson (1983) and Edward SoJa (1996) with the ideas of brilliant writers and litterateurs like Milan Kundera or Andrzej STAsIUK. It is broadly known that geography is an interdisciplinary field of science but geo-poetics in the border zone of geography and literature has been a less known sub-discipline up until today. With the publishing of Imagined Geographies not only the Central Europe debate gets enriched with new theories, ideas, and information, but the readers (both academic and non-academic) can discover a new domain of the discourse - the spatial narratives constructed by literature.

Acknowledgement: Research for this publication has been supported from the National Research, Development and Innovation Fund (NKFIA) grant number K 124291.

BÁLINT KRONSTEIN ${ }^{1}$

\section{REFERENCES}

Anderson, B. 1983. Imagined Communities: Reflections on the Origin and Spread of Nationalism. New YorkLondon, Verso.

Kundera, M. 1984. The tragedy of Central Europe. The New York Review of Books 31. (7): 33-37.

SAID, E. 1978. Orientalism: Western Concepts of the Orient. New York, Pantheon Books.

SojA, E. W. 1996. Thirdspace: Journeys to Los Angeles and Other Real-and-Imagined Places. Hoboken, Blackwell.

\footnotetext{
${ }^{1}$ Department of Social and Economic Geography, Institute of Geography and Earth Sciences, Eötvös Loránd University (ELTE), Budapest, Hungary. E-mail: balintkronstein@gmail.com
} 